\title{
Gli spazi-tra. Connettere Palermo. Analisi morfologica del tessuto urbano di Palermo
}

Sonia Mercurio

Abstract

La ricerca in oggetto ha come proposito di inserirsi nel dibattito contemporaneo rispetto al tema dell'in between, tentando di analizzare la città contemporanea alla luce del pensiero elaborato su questo tema a partire dagli studi teorici elaborati dal Team X. L'intento sarà quello di studiare lo spazio 'tra le cose' della città con specifico riferimento alla città di Palermo.

Lo spazio in between - tra le cose - è appunto luogo delle connessioni, in cui il fuoco dell'indagine si sposta sulle relazioni che trascendono l'architettura materica, pur lasciando intendere implicitamente la sua esistenza. 'Connettere' è l'operazione che lo spazio in between ontologicamente svolge, nel momento in cui separa e tende verso. L'in between è, come Prometeo stesso, l'archetipo absolutus, sciolto da limitazioni. È uno spazio ambiguo, effimero, immateriale e ambivalente, come ambivalente è la natura dell'uomo.

La ricerca, partendo dalla rilettura del rilievo si awarrà di operazioni di decostruzione, elencazione, accostamento, al fine di leggere la struttura 'morfologica' su cui poter fondare consapevolmente il progetto contemporaneo della città.

Parole chiave

archetipo, in between, rilievo, morfologia urbana, relazione.
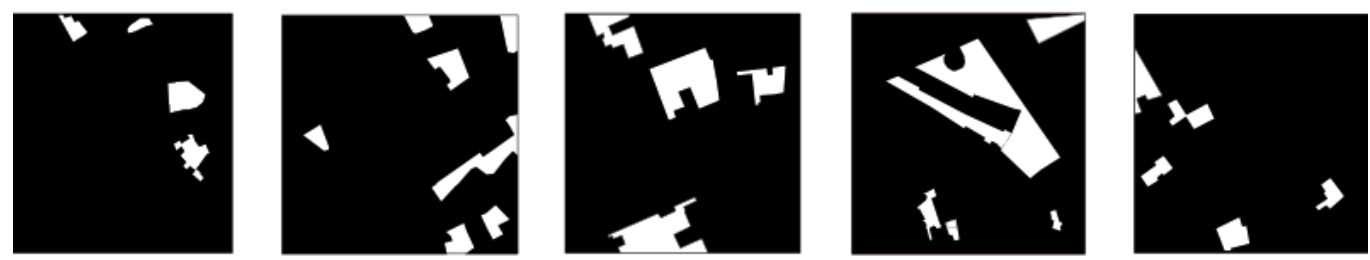
L'analisi urbana di tessuti fortemente storicizzati non sempre risulta di immediata lettura, soprattutto nel momento in cui si cerca una dimensione spaziale così rarefatta e così poco connotata da essere difficilmente definibile come quella degli in between places.

Nell'atto dell'investigare sopra questo tema diviene, pertanto, necessario fare ricorso alla letteratura che anche solo marginalmente ha fatto riferimento a questo campo di indagine. Cosicché risulta evidente imbattersi in una casistica cospicua di definizioni che provano a connotare, sebbene definendolo con sostantivi diversi, uno stesso concetto. Un concetto ambiguo, effimero, immateriale. Uno spazio ambivalente, come ambivalente è la natura dell'uomo.

L'in between è terreno comune "in cui si scontrano le polarità che possono nuovamente diventare fenomeni gemelli" come definisce Van Eyck [Strauven 1998], terreno in cui si innestano le relazioni tra polarità, "tra il passato e il presente, il classico e il moderno, l'arcaico e l'avanguardia, la permanenza e il cambiamento, la semplicità e la complessità" [Spirito 20 I5, p. 46-49].

L'obiettivo che la ricerca in oggetto si propone è dunque quello di rintracciare l'elemento 'infra' quale parte costituente di un tessuto complesso e parte componente attraverso la quale "fabbrichiamo l'immagine della realtà" [Ugo 1976, p. 3 I-40], partendo dall'astrazione di paradigmi di lettura provenienti dalla letteratura che fa seguito al Team $X$. Elemento non certo come dato semplice o semplificato, ma come momento elementare, e quindi nodo nel quale si condensa la massima complessità.

Le considerazioni rispetto a fenomeni urbani di questo tipo permettono di includere all'interno della città consolidata questi nuovi territori contemporanei che, rifiutando tali meccanismi dicotomici, lavorano sugli aspetti e su organismi unificanti e quindi sulle aree di relazione, che trovano proprio negli in between della città il proprio sedime fertile.
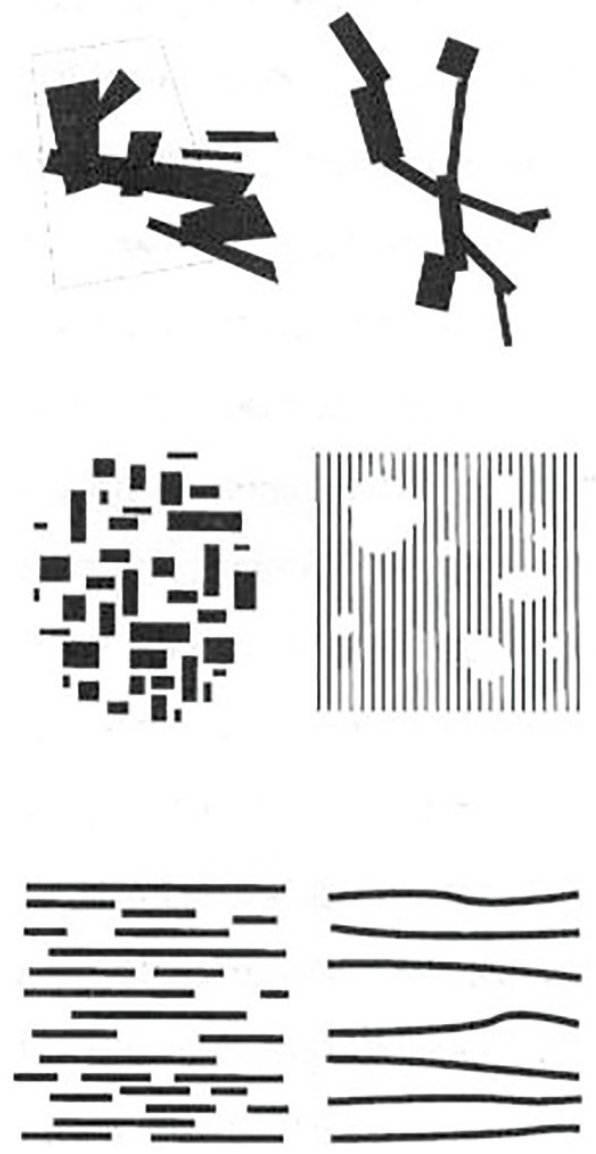
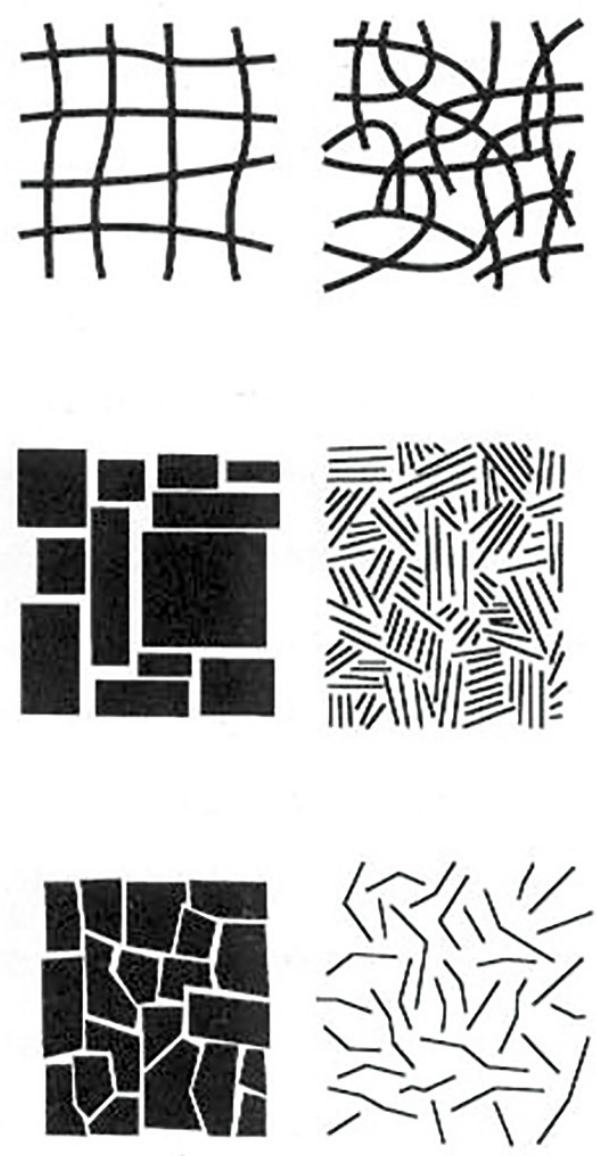
"Tra interno ed esterno, tra soggetto e oggetto tra terreno e ultraterreno, tra realtà e illusione c'è dunque un processo dinamico di continua interazione caratterizzato da un elevato livello di flessibilità e di scambio interattivo, in virtù del quale il gioco degli opposti non separa, ma integra. I ruoli, le funzioni si ribaltano di continuo e si donano reciprocamente senso. Si ha così un esplicito distacco dall'usuale modalità di pensiero accentrato sulla sostanza, al quale subentra l'idea che, come modalità primitiva ed equipollente del reale, vada assunta la relazione" [Tagliagambe 2008, p. 10-40].

Questa nuova lettura dell'urbano vede, dunque, quale elemento strutturale della propria trama, I'intra', ovvero, la sua struttura relazionale sia sul piano materiale-tangibile, che su quello simbolico, ma anche su quello politico muovendo dall'emergere di un sistema complesso di "spazialità intermedie" [Amin, Thrift 200 I].

Queste spazialità intermedie, però, non rimandano esclusivamente alle trasformazioni morfologiche in atto nelle città. La trasformazione urbana contemporanea, pertanto non è, unicamente riconducibile, a fenomeni evolutivi quali la crescita demografica, l'estensione della superficie edificata, la disseminazione degli insediamenti urbani. Tali fenomeni, infatti, benché siano oltremodo rilevanti prescindono dall'epifania del fenomeno, un processo ben più complesso di cambiamento in profondità del metabolismo urbano, multidimensionale e profondo, definito "uno spostamento verso un ordine e una configurazione significativi della vita sociale, economica e politica [...], una combinazione sequenziale di disgregazione e di ricostruzione, derivanti da talune incapacità o perturbazioni nei sistemi di pensiero e di azione stabiliti" [Soja 1989]. Tale processo di trasformazione del metabolismo urbano rimane sfaccettato, non lineare, imprevedibile e aperto. La 'città intermedia', da questa prospettiva, diviene un processo di ridefinizione, ancora in transizione, dell'insieme di relazioni che tessono il farsi delle formazioni urbane contemporanee [Sieverts 2003, Young et al. 20l I], "continuamente rimaneggiato attraverso il processo di trasformazione" [Brenner 20 I4]. Questo spazio in between è candidato a divenire lo spazio privilegiato di indagine della questione urbana contemporanea, proprio per le opportunità che genera all'interno del contesto urbano e per la carica relazionali e potenziale che riveste.

II termine in-between, infatti, è la traduzione della parola greca metaxy, avverbio con valore preposizionale, composto da metá (in mezzo, tra) e sún (con, assieme, unitamente a): esso denota lo spazio che sta in mezzo e mette in relazione.

Risulta essere, pertanto, una parola che mantiene un'ambivalenza di aspetti logicamente antitetici: da un lato indica uno stato di separazione, dall'altro un movimento d'approssimazione sottolineando tanto la distanza esistente tra due termini quanto la loro prossimità.
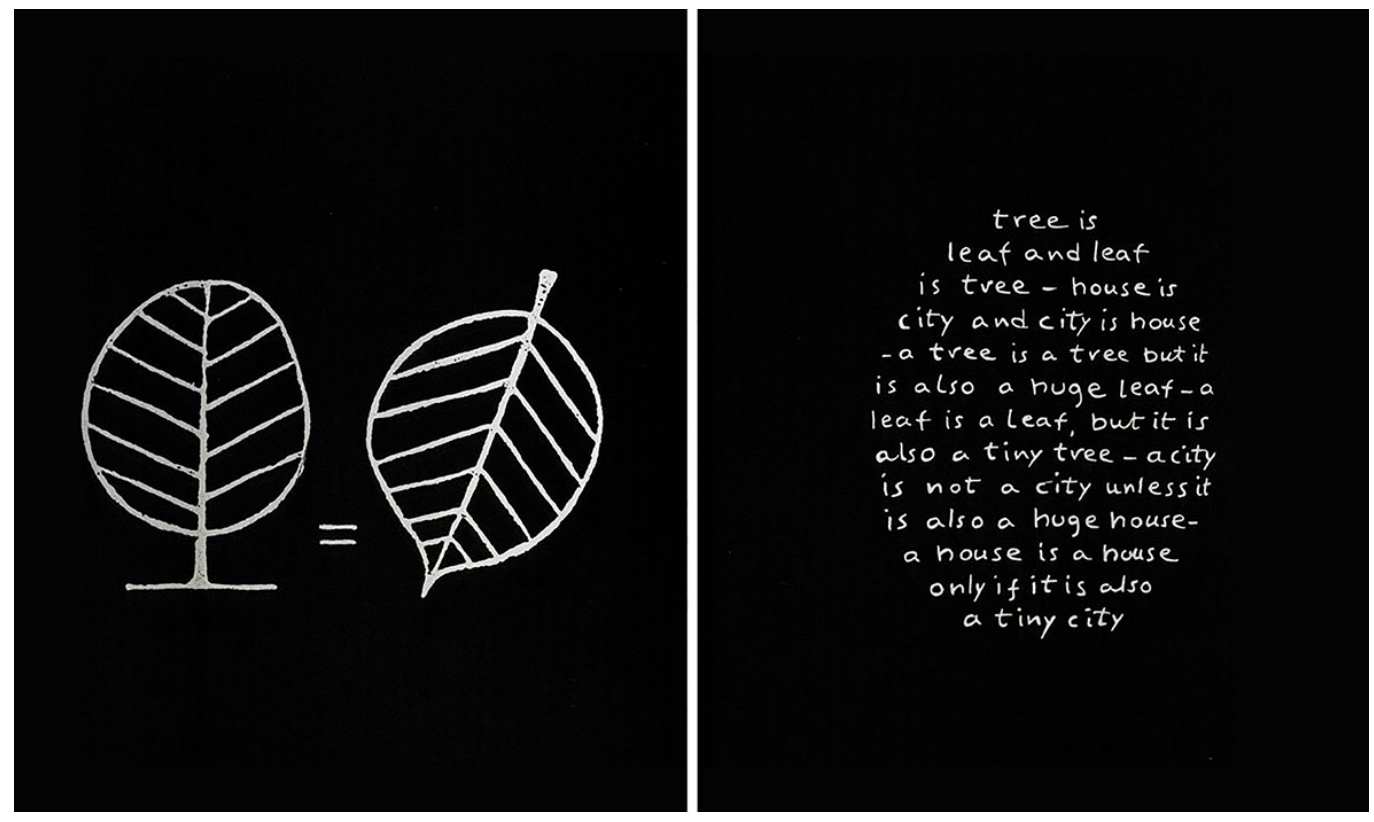
Rispetto alla corrente di pensiero afferente al Team X, i primi a introdurre questo termine con riferimento puro all'idea architettonica furono Alison e Peter Smithson, i quali conferirono alle testimonianze scritte un momento fondamentale nella loro vita professionale, sia quale preambolo di quelle idee che non erano ancora riusciti a realizzare, a materializzare, sia anche quale strumento ex post per ridefinire e avvalorare il realizzato, alimentando nuovamente e circolarmente il processo del pensiero. The Space Between [Oppositions 1974], infatti, fu un breve scritto pubblicato in memoria di Louis Kahn, le cui linee di apertura racchiudono alcune delle idee già presenti in entrambi i libri The Charged Void [I], nei quali gli architetti affermavano, riferendosi agli spazi vissuti che "i più misteriosi, i più carichi di forme architettoniche sono quelli che catturano l'aria vuota".

The Space Between pone l'attenzione più nelle relazioni che nei manufatti in sé, nei luoghi che trascendono le architetture stesse. L'attenzione si centra nell'effetto che si sta producendo nel momento in cui si superano i propri limiti, nella definizione dello spazio intorno. Infatti, il titolo stesso, The Space Between - lo spazio intermedio - non è del tutto casuale e lascia intendere implicitamente l'esistenza della materia sebbene l'attenzione non si ponga in essa [Ábalos Ramos 20 17].

Francis Strauven, analizzando l'opera di Van Eyck, ha citato tre tipi di metodo per fondere la forma, in relazione allo "spazio tra le cose": I) un link tra due diversi spazi interni; 2) un duplice fenomeno a livello strutturale da completo reciproco l'interpenetrazione, la fusione totale di due modelli diversi per formare una struttura nuova e complessa; 3) la parte e l'insieme, in particolare due aree a diversi livelli di configurazione, dando parte e tutta strutture analoghe, possono essere resi equivalenti in linea di principio nonostante le loro differenze [Strauven 1998].

II piccolo, dunque, implica gli stessi valori e significati del grande, e il grande diventa comprensibile attraverso il piccolo (fig. 3). La questione scalare, dunque, rispetto agli in between spaces, diviene pressoché irrilevante e questi territori indefiniti fungono da occasione per un ripensamento complessivo del 'disegno' della città.

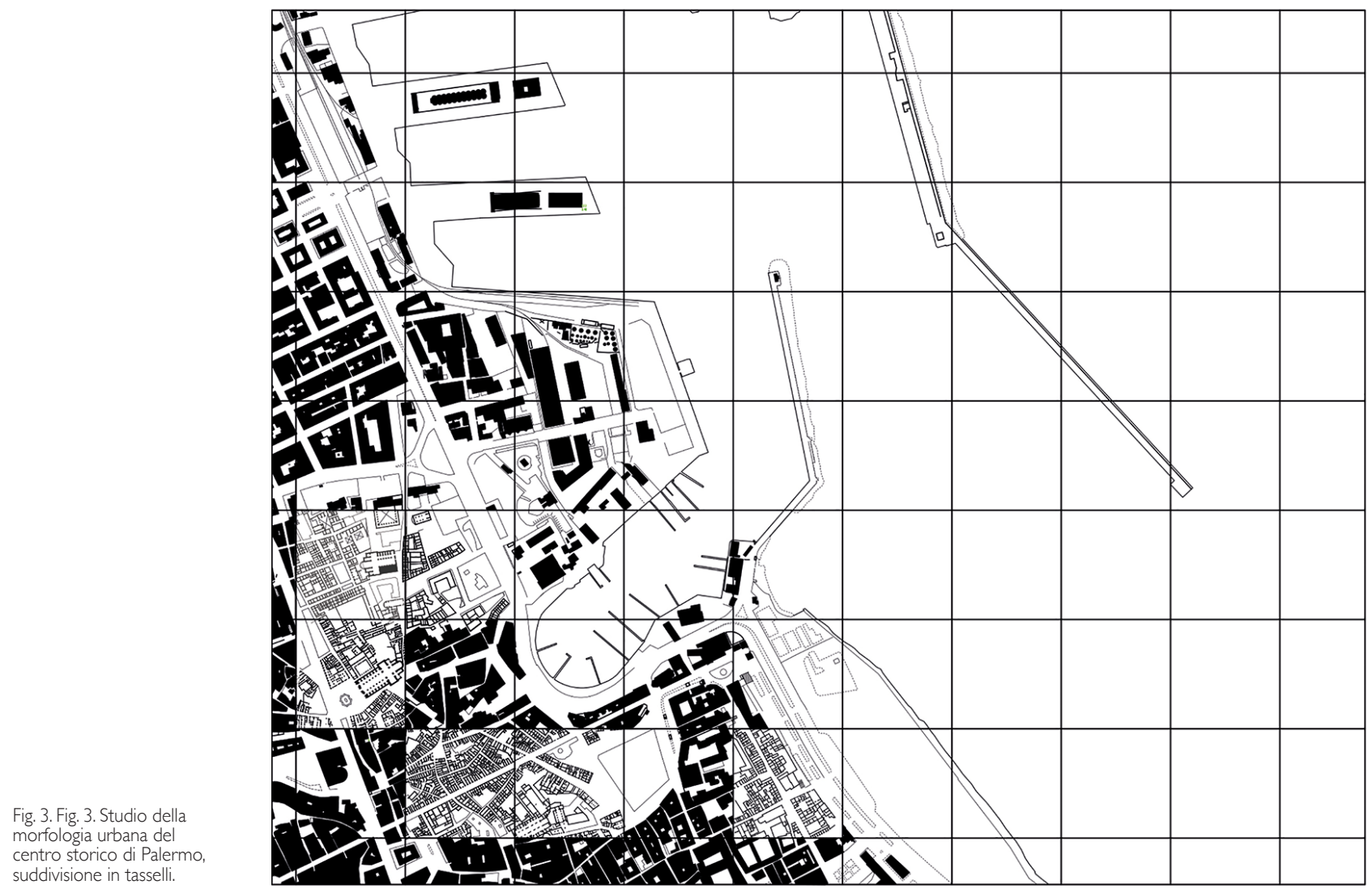



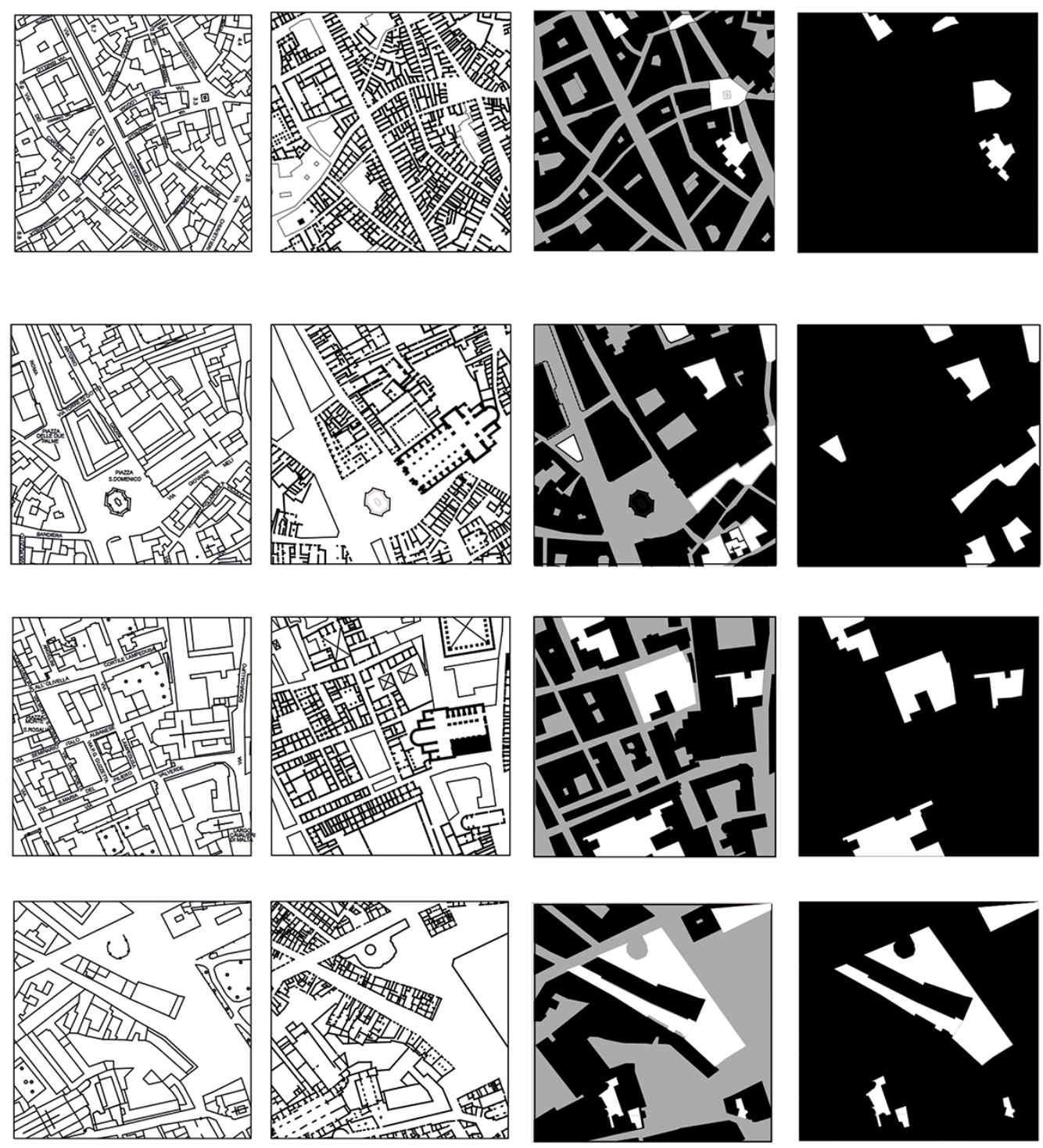

Fig. 4. Decostruzione
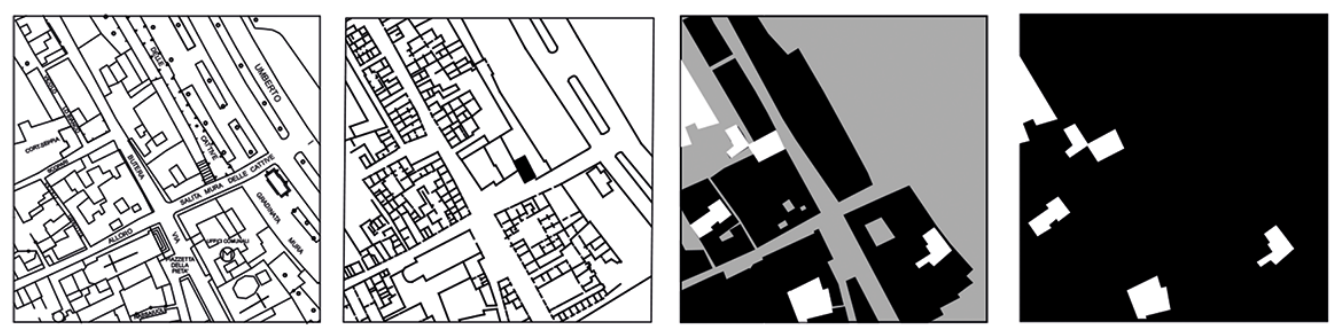


\section{Un caso studio: Palermo}

"Frammento, segno e traccia emergono dall'intricata disorganicità contemporanea e il panorama diventa quello di uno spazio composito fatto di elementi sovrapposti" [Bertelli 20 I2]. Partendo da tali considerazioni, annotazioni e definizioni del tema, la ricerca risulta essere parte di un lavoro più ampio di ricerca che avrà come oggetto l'individuazione di questi spazi in between nella analisi morfologica di alcune città che si affacciano nel bacino mediterraneo al fine di evidenziare analogie e mutamenti di questi spazi, creando un alfabeto degli 'spazi-tra', che descriverà 'figure' morfologiche, che però intendono rappresentare sistemi complessi [Ginex 2017].

La città di Palermo, tra queste, racconta di un tessuto urbano con uno spessore importante, legato al tempo, un sedimento di materiale stratificato e complesso, nel quale andare a individuare tracce nascoste o scomparse, a tratti visibili e presenti allo sguardo o ancora non ben riconoscibili.

Una città in cui le guerre succedutesi e le volontà politiche hanno fatto si che fosse spesso distrutto, manomesso, e sui vuoti conseguenti alle distruzioni, o rimanessero aperte ferite o venissero costruiti altri contenitori. Una città che conserva memorie e ritagli di molte culture filtrate dalla tradizione locale [De Simone 1982].

Uno spessore che costituisce la dimensione nascosta ma costituente il paesaggio, urbano e non, materiale d'indagine e substrato per il recupero di quei segni latenti a cui ancorare le trasformazioni future, a seguito di una lettura diacronica, che lascia affiorare una struttura 'morfologica' su cui poter fondare consapevolmente il progetto contemporaneo della città. Lo studio della forma urbana, applicata a questa 'città-porta', coinvolge tutte le scale fisiche dell'abitare, dall'architettura al territorio, definendosi per la capacità d'individuare, un sistema di segni 'strutturali' in grado di spiegare le forme dell'abitare o la complessità dell'aggregato urbano, e il suo costruirsi in divenire. Un sistema di segni, aperto alla modificazione, capace di riunire, senza confonderle, l'analisi con la sintesi, l'universale e il particolare, la 'lettura' con il progetto [De Simone 1982].

Il lavoro realizzato si avvale di operazioni di decostruzione in unità minime verso una rappresentazione dell'ambiente fisico, che è, difatti, mai un processo neutrale. Esiste un rapporto tra cosa osservata e rappresentazione della cosa, tra significato e segno che è chiaramente leggibile, e personale rispetto alla 'cosa' analizzata.

L'esperienza di analisi partendo dalla rilettura del rilievo (fig. 6) funge da esperienza per riflettere, pensare, progettare, ricercando nell'urbano in modo specifico a partire dalla forma dagli elementi costitutivi ma anche dal senso sotteso e dai simboli che ne esprimono realtà interne.

II rilievo si fa, dunque, documento di testimonianze che "la storia ci consegna" [De Simone 1982], strumento primario di riflessione di lettura di segni.

In questo caso ciò che si pone come oggetto dello sforzo scientifico è proprio la lettura critica di un manufatto complesso come un centro storico articolato nei luoghi, strutturato nelle gerarchie con una variabile temporale dilatata, nel tentativo di "rappresentare gli spazi, i relativi elementi costitutivi e i reciproci legami sintattici" [Ginex 20 I7] di un tessuto urbano vivo fatto di "pietre e carne".

\section{Note}

[I] The Charged Void:Architecture (200 I) e The Charged Void: Urbanism (2005), pubblicati entrambi da Monicelli Press, New York, precedono il terzo scritto pubblicato da Alison e Peter Smithson che si intitolerà appunto The Space Between.

\section{Riferimenti bibliografici}

AA.V. (1982). Palermo: la memoria costruita, Quaderni della "Collana di Pietra". Palermo: S. F. Flaccovio Editore.

Ábalos Ramos Ana (2017). The Space Between. Alison and Peter Smithson. In VLC arquitectura, vol. 4, Issue I, pp. I75- I8I. 
Amin Ash, Thrift Nigel (200I). Cities Reimagining the Urban. Cambridge: Polity Press.

Bertelli Guya (2002). Frammenti, scritti di architettura. Milano: Libreria Clup.

Brenner Neil (2014). Implosions/Explosions:Towards a Study of Planetary Urbanization. Berlin: Jovis.

Ginex Gaetano (2002). Aldo Van Eick. L'enigma della forma. Torino:Testo \& Immagine.

Ginex Gaetano (2017). Nefta e le città oasi di Tamerza,Mides e Chebika. "Città prima delle sabbie". Reggio Calabria: liriti Editore.

Sieverts Tom (2003). The In-Between City as an Image of Society: From the 19 Impossible Order Towards a Possible Disorder in the Urban Landscape. In Keil Roger, Wood Patricia, and Young Douglas (eds.). (20I I). In-Between Infrastructure: Urban Connectivity in an Age of Vulnerability. Toronto: Praxis (e)Press, pp. 19-27.

Soja Edward (1989). Postmodern geographers. London:Verso.

Spirito Gianpaola (20I5). In-between places: forme dello spazio relazionale dagli anni Sessanta a oggi. Macerata: Quodlibet. Strauven Francis (1998). Aldo van Eyck. The shape of relativity. Amsterdam: Architectura \& Natura.

Tagliagambe Silvano (2008). Lo spazio intermedio. Rete, individuo e comunità. Milano: Università Bocconi Editore.

Ugo Vittorio (1976). Forma progetto architettura. Palermo.

Autore

Sonia Mercurio, Università Mediterranea di Reggio Calabria, sonia.mercurio@unirc.it

Per citare questo capitolo: Mercurio Sonia (2020). Gli spazi-tra. Connettere Palermo. Analisi morfologica del tessuto urbano di Palermo/ln between Places. Connecting Palermo. Morphological analysis of the urban tissue of Palermo. In Arena A., Arena M., Brandolino R.G., Colistra D., Ginex G., Mediati D., Nucifora S., Raffa P. (a cura di). Connettere. Un disegno per annodare e tessere. Atti del $42^{\circ}$ Convegno Internazionale dei Docenti delle Discipline della Rappresentazione/Connecting. Drawing for weaving relationships. Proceedings of the 42th International Conference of Representation Disciplines Teachers. Milano: FrancoAngeli, pp. 644-657. 


\title{
In-between Places. Connecting Palermo. Morphological Analysis of the Urban Tissue of Palermo
}

\author{
Sonia Mercurio
}

Abstract

This research aims to take part in the contemporary debate on the theme of 'in between', trying to analyze the contemporary city through the thought elaborated about this theme starting from the theoretical studies elaborated by Team X. The intent will be to study the space 'among things' of the city with specific reference to the city of Palermo.

The space in between is precisely the place of connections, in which the focus of the investigation moves on the relationships that transcend the material architecture, while implicitly leaving its existence understood. 'Connecting' is the operation that space in between ontologically carries out, when it separates and tends towards. The 'in between' is, like Prometheus himself, l'archetype 'absolutus', free from limitations. It is an ambiguous, ephemeral, immaterial and ambivalent space, as the nature of man is ambivalent.

The research, starting from the re-reading of the survey will use deconstruction, listing, matching, in order to read the 'morphological' structure on which consciously basing the contemporary project of the city.
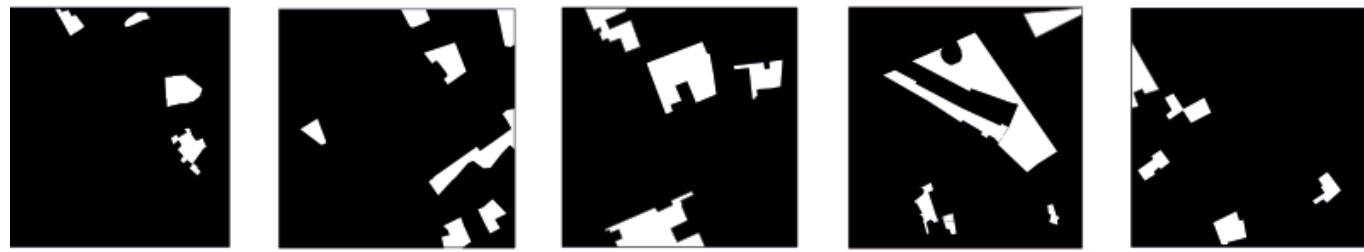
The urban analysis of strongly historicized tissues is not always immediately readable, especially when we are looking for a spatial dimension so rarefied and not much defined to be hardly definable, as that of the 'in between' places.

In the act of investigating this theme it becomes, therefore, necessary to resort to literature which even marginally referred to this field of investigation. Thus it is evident to come across a conspicuous case of definitions that try to connotate, although defining it with different nouns, a same concept. An ambiguous, ephemeral, immaterial concept. An ambivalent space, as ambivalent, is the nature of man.

L'in between is a common ground 'in which polarities collide which may again become twin phenomena' as Van Eyck says [Strauven 1998], a terrain in which the relationships between polarity are grafted, "between past and present, classical and modern, archaic and avant-garde, permanence and change, simplicity and complexity" [Spirito 20 I 5, 46-49].

This research aims, therefore, to trace the element 'infra' as a constituent part of a complex tissue and a component part through "manufacturing the image of reality" [Ugo | 976, 3 I-40], starting from the abstraction of reading paradigms coming from the literature that follows Team X. Element, certainly, not as simple or simplified data, but as elementary moment.

Considerations regarding this kind of urban phenomena allow to include within the consolidated city these new contemporary territories. These territories, rejecting such dichotomic mechanisms, work on the unifying of aspects and organisms and above all on the relationship areas, which find their fertile ground in the city's in between.

"Between interior and exterior, between subject and object between terrain and otherworIdly, between reality and illusion there is a dynamic process of continuous interaction characterized by a high level of flexibility and interactive exchange, by virtue of which the game
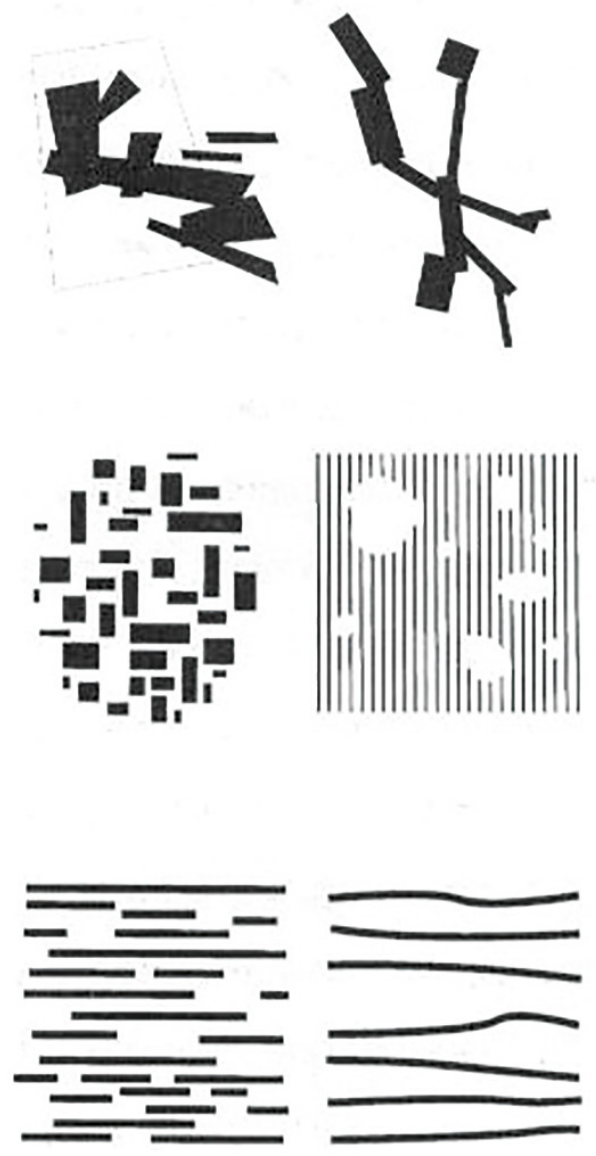
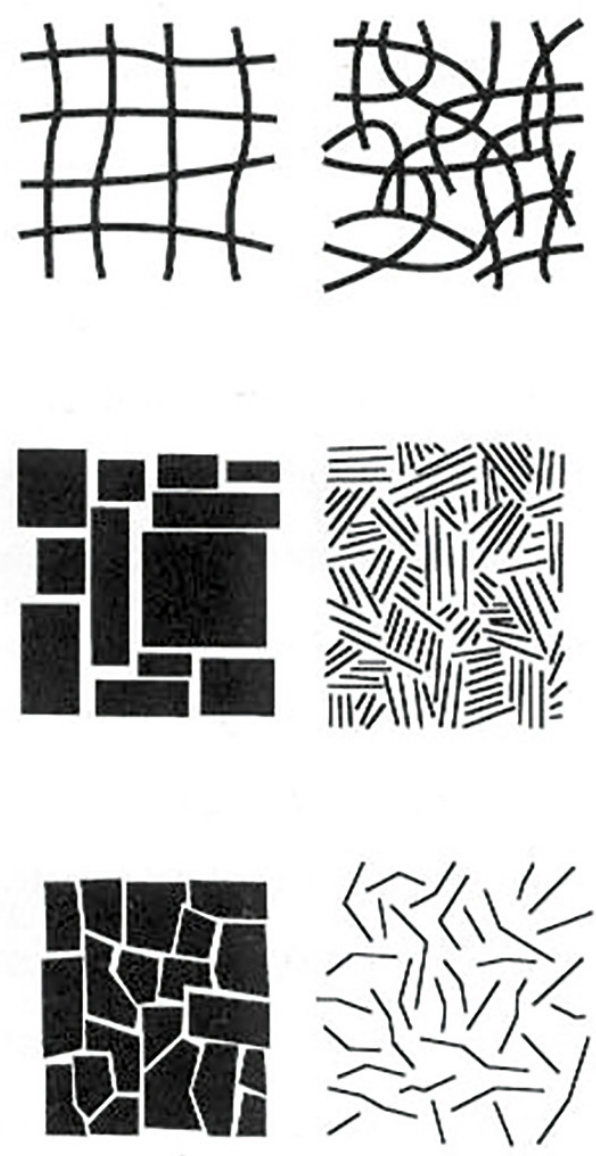
of opposites does not separate, but integrates. The roles, the functions are constantly reversed and give each other meaning. Thus there is an explicit detachment from the usual mode of thought centered on substance, replaced by the idea that, as a primitive and equivalent mode of reality, the relation should be assumed" [Tagliagambe 2008, 3 I-40].

This new way to read the urban tissues, therefore, takes,as a structural element of its plot, the 'infra-space', that is its relational structure both on the material-tangible plane, that on the symbolic one, but also on the political one moving from the emergence of a complex system of "intermediate spatiality" [Amin, Thrift 200 I].

These intermediate spatialities, however, are not referred exclusively to the morphological transformations taking place in the cities. The contemporary urban transformation, therefore, is not solely attributable to evolutionary phenomena such as population growth, the extension of the built-up area, the dissemination of urban settlements. These phenomena, in fact, although they are very relevant, do not take into account the epiphany of the phenomenon, a much more complex process of change in depth than the urban metabolism, multidimensional and deep, defined "a shift towards a significant order and configuration of social, economic, and political life [...], a sequential combination of falling apart and building up again, deconstruction and attemted reconstituion, arising, from, certain incapacities or perturbations in established systems of thought and action" [Soja 1989].

This process of transformation of urban metabolism remains multifaceted, non-linear, unpredictable and open. 'Intermediate city', from this perspective, becomes a process of redefinition, still in transition, of the set of relationships that weave the making of contemporary urban [Sieverts 2003, in Young et al. 20 I I] formations,"'continuously restructured through the transformation process" [Brenner 2014].

This space in between is expected to become the privileged space for investigating the contemporary urban issue, precisely because of the opportunities it generates within the urban context and because of the relational and potential charge it holds.

The term 'in-between', in fact, is the translation of the Greek word metaxy, adverb with prepositional value, composed of half (in the middle, between) and sún (with, together, together with): it denotes the space that stands in the middle and at the same time that puts in relation. It appears, therefore, to be a word that maintains an ambivalence of logically antithetical aspects: on the one hand it indicates a state of separation, on the other an approximation movement emphasizing both the existing distance between two terms and their proximity.
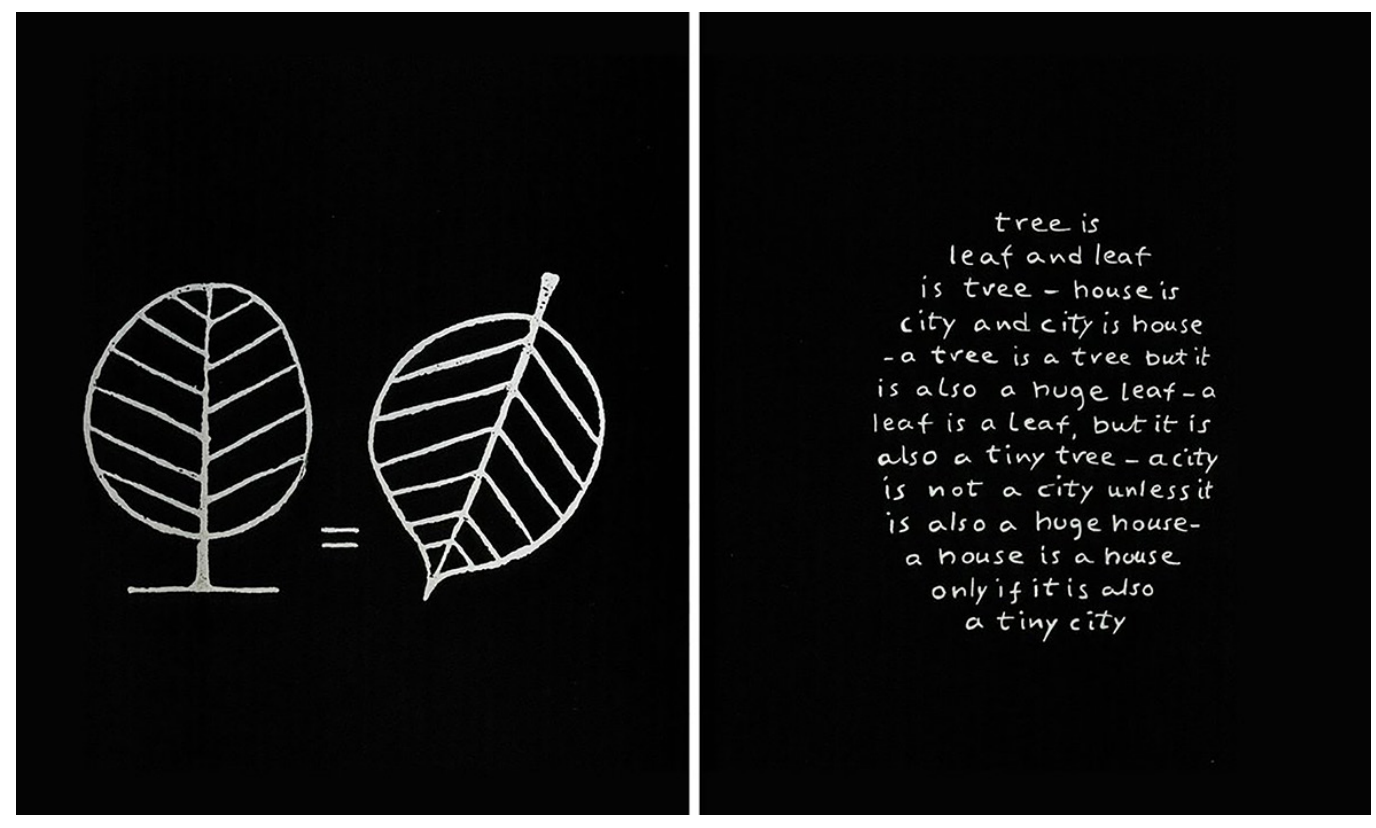
With respect to Team X's current of thought, the first to introduce this term with pure reference to the architectural idea were Alison and Peter Smithson, who gave to the written testimony a fundamental moment in their professional life, both as a preamble to those ideas that they had not yet succeeded in realizing, in materializing, and also as an ex-post tool to redefine and validate the realization, re-energising and circulating the process of thought. The Space between [Oppositions 1974], in fact, was a short written in memory of Louis Kahn, whose opening lines enclose some of the ideas already present in both books The charged void [I] in which the architects affirmed, referring to the lived spaces that "the most mysterious, the most loaded of architectural forms are those that capture the empty air".

The Space between puts the attention more in the relationships than in the manufactures in itself, in the places that transcend the same architectures. The attention is focused on the effect that is being produced when you exceed your limits, in the definition of the space around. In fact, the title itself, The Space between- the intermediate space - implies the existence of matter although attention is not placed in it [Ábalos Ramos 20 I7].

Francis Strauven, analyzing Van Eyck's work, cited three types of method to merge the form, in relation to "the space between things": I) a link between two different interior spaces; 2) a dual structural phenomenon from complete mutual interpenetration, the total fusion of two different models to form a new and complex structure;

3) the part and the whole, in particular two areas at different levels of configuration, giving part and all similar structures, can be made equivalent in principle despite their differences [Strauven 1998].

The small, therefore, implies the same values and meanings of the great, and the great becomes understandable through the small (fig. 3). The question of scaling, therefore, with respect to in between spaces, becomes almost irrelevant and these indefinite territories serve as an occasion for a total rethinking of the 'design' of the city.

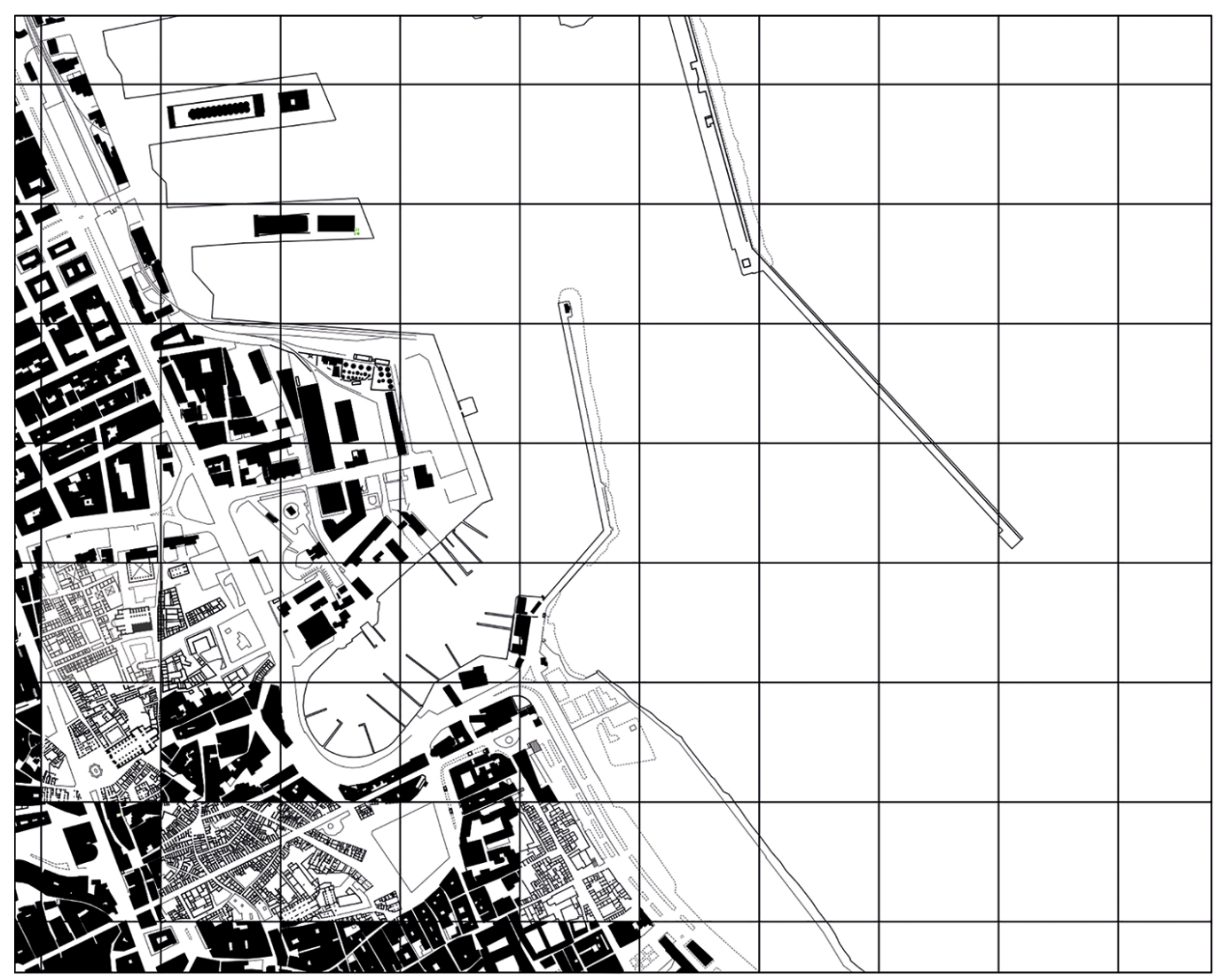



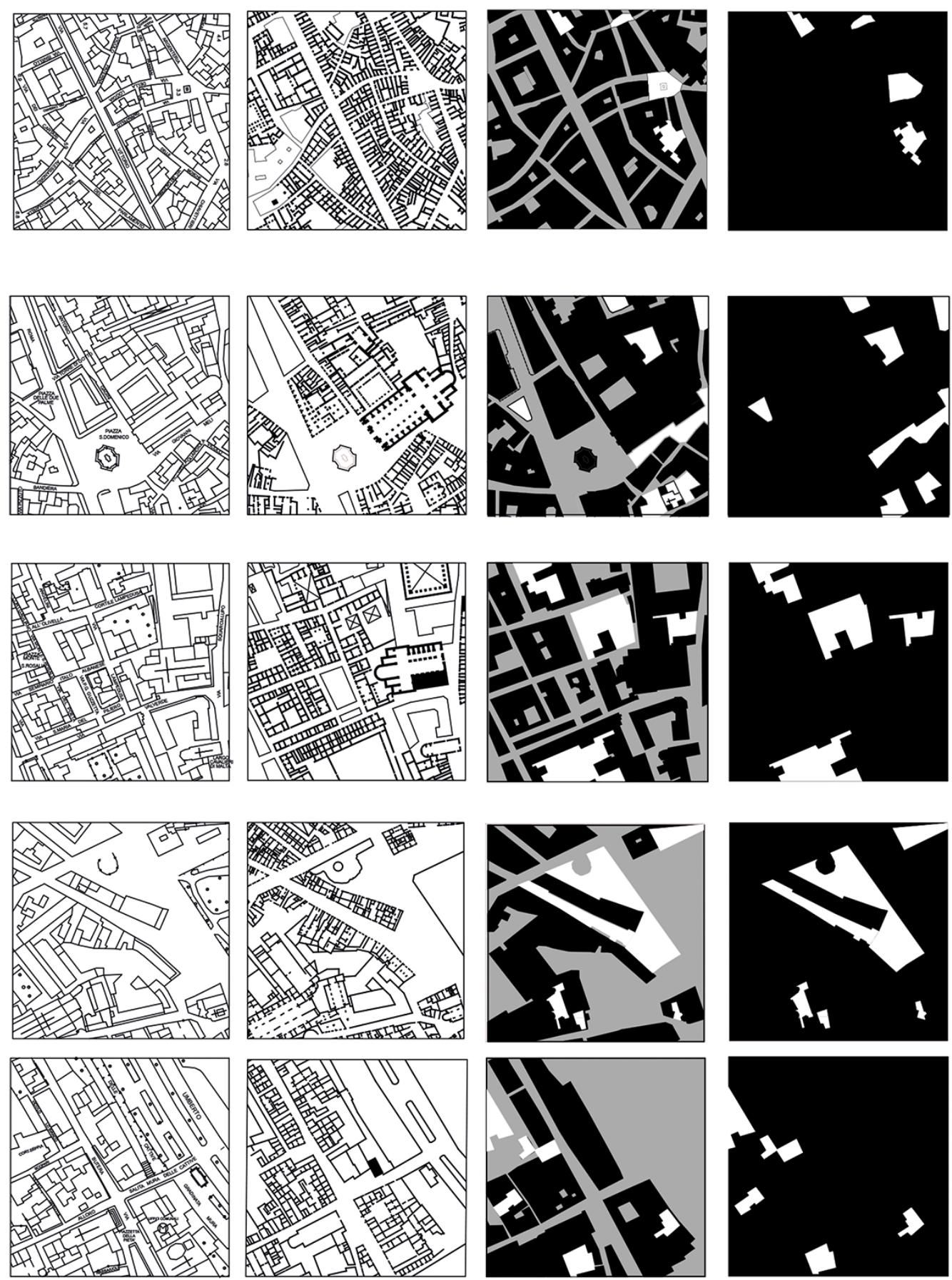


\section{Palermo: a case study}

"Fragment, sign and trace emerge from the intricate contemporary disorganism and the landscape becomes that of a composite space made of overlapping elements" [Bertelli 20 I2]. Starting from these considerations, annotations and definitions of the theme, the research results to be part of a wider research work that will focus on the identification of these spaces in between in the morphological analysis of some cities that overlook the Mediterranean basin in order to highlight analogies and changes of these spaces, creating an alphabet of 'spaces-between', which will describe morphological 'figures', that intends to represent complex systems [Ginex 2017$]$.

The city of Palermo, among them, is an urban tissue with an important thickness, related to time, a sediment of stratified and complex material, in which to locate hidden traces or disappeared, at times visible and present to the eyes or still not well recognizable.

A city destroyed several times by wars and political will, tampered with, where there were open wounds and other containers were built. A city that preserves memories and cuttings of many cultures filtered by local tradition [De Simone 1982].

A thickness that constitutes the hidden dimension but constituting the landscape, urban and not, material of investigation and substratum for the recovery of those latent signs to which anchor the future transformations, following a diachronic reading, which allows to emerge a 'morphological' structure as a base for the contemporary project of the city.

The study of the urban form, applied to this 'city-gate', involves all the physical scales of the inhabit, from the architecture to the territory, defining itself for the ability to locate, a system of structural 'signs', able to explain the forms of living or the complexity of the urban cluster, and its building in the future. A system of signs, open to modification, capable of bringing together, without confusing them, analysis with synthesis, the universal and the particular, 'reading' with the project [De Simone 1982].

The work carried out uses deconstruction operations in minimal units towards a representation of the physical environment, which is, in fact, never a neutral process. There is a relationship between the observed thing and the representation of the thing, between the meaning and the sign that is clearly readable, and personal with respect to the "thing" analyzed.

The experience of analysis starting from the re-reading of the survey (fig. 6) serves as an experience to reflect, think, design, researching in the urban field, in a specific way, starting from the form of the constituent elements but also from the underlying meaning and symbols that express its internal realities.

The survey, therefore, becomes a document of testimonies that "history gives us" [De Simone 1982], the primary instrument of reflection and reading of signs.

In this case what is the object of the scientific work is precisely the critical reading of a complex artifact like a historical center articulated in the places, structured in the hierarchies with a dilated temporal variable, in the attempt of "represent spaces, their constituent elements and their syntactic links" [Ginex 20 I7] of a living urban fabric made of "stones and flesh".

\section{Notes}

[I] The Charged Void:Architecture (200I) and The Charged Void: Urbanism (2005), both published by Monicelli Press, New York, precede the third paper published by Alison and Peter Smithson which will be titled The Space Between.

\section{References}

AA.W. (1982). Palermo: la memoria costruita, Quaderni della "Collana di Pietra". Palermo: S. F. Flaccovio Editore.

Ábalos Ramos Ana (2017). The Space Between. Alison and Peter Smithson. In VLC arquitectura, vol. 4, Issue I, pp. I75-I8I. 
Amin Ash, Thrift Nigel (200I). Cities Reimagining the Urban. Cambridge: Polity Press.

Bertelli Guya (2002). Frammenti, scritti di architettura. Milano: Libreria Clup.

Brenner Neil (2014). Implosions/Explosions:Towards a Study of Planetary Urbanization. Berlin: Jovis.

Ginex Gaetano (2002). Aldo Van Eick. L'enigma della forma. Torino:Testo \& Immagine.

Ginex Gaetano (2017). Nefta e le città oasi di Tamerza,Mides e Chebika. "Città prima delle sabbie". Reggio Calabria: liriti Editore.

Sieverts Tom (2003). The In-Between City as an Image of Society: From the 19 Impossible Order Towards a Possible Disorder in the Urban Landscape. In Keil Roger, Wood Patricia, and Young Douglas (eds.). (20I I). In-Between Infrastructure: Urban Connectivity in an Age of Vulnerability. Toronto: Praxis (e)Press, pp. 19-27.

Soja Edward (1989). Postmodern geographers. London:Verso.

Spirito Gianpaola (20I5). In-between places: forme dello spazio relazionale dagli anni Sessanta a oggi. Macerata: Quodlibet. Strauven Francis (1998). Aldo van Eyck. The shape of relativity. Amsterdam: Architectura \& Natura.

Tagliagambe Silvano (2008). Lo spazio intermedio. Rete, individuo e comunità. Milano: Università Bocconi Editore.

Ugo Vittorio (1976). Forma progetto architettura. Palermo.

\section{Author}

Sonia Mercurio, Università Mediterranea di Reggio Calabria, sonia.mercurio@unirc.it

To cite this chapter:: Mercurio Sonia (2020). Gli spazi-tra. Connettere Palermo. Analisi morfologica del tessuto urbano di Palermo/ln between Places. Connecting Palermo. Morphological analysis of the urban tissue of Palermo. In Arena A., Arena M., Brandolino R.G., Colistra D., Ginex G., Mediati D., Nucifora S., Raffa P. (a cura di). Connettere. Un disegno per annodare e tessere. Atti del $42^{\circ}$ Convegno Internazionale dei Docenti delle Discipline della Rappresentazione/Connecting. Drawing for weaving relationships. Proceedings of the 42th International Conference of Representation Disciplines Teachers. Milano: FrancoAngeli, pp. 644-657. 